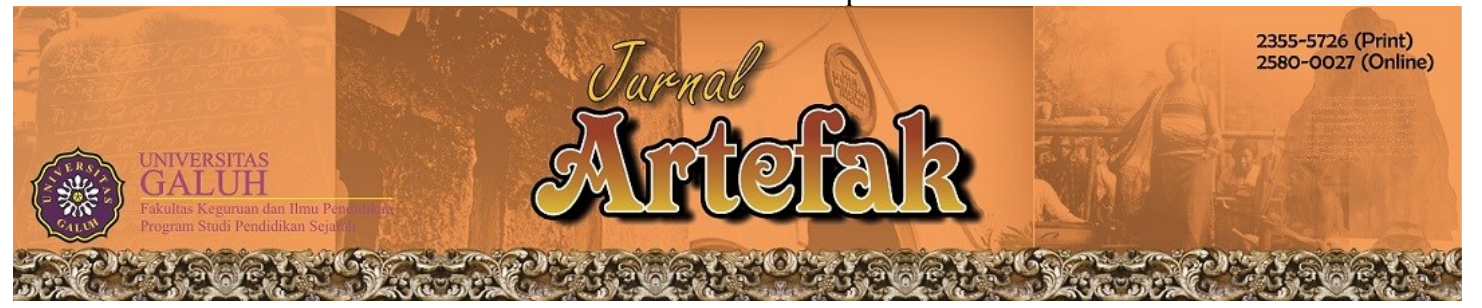

https://jurnal.unigal.ac.id/index.php/artefak/article/view/5454

\title{
COLONIAL TOWN PONTIANAK: PROSES TERBENTUK \\ DAN PERKEMBANGANYA PADA MASA VEREENIGDE OOST-INDISCHE COMPAGNIE (VOC) TAHUN 1779-1791
}

\author{
Haris Firmansyah \\ Universitas Tanjungpura, Indonesia \\ Email: harisfirmansyah@untan.ac.id
}

Sejarah Artikel: Diterima 7-7-2021 Disetujui 1-8-2021 Dipublikasikan 30-9-2021

\begin{abstract}
Abstrak
Penelitian ini bertujuan mengetahui bagaimana proses awal terbentuknya kota kolonial dan perkembanganya di Pontianak pada masa Vereenigde Oost-Indische Compagnie (VOC) yang berlangsung dari tahun 1779-1791. Metode penelitian yang digunakan dalam penelitian ini adalah metode penelitian sejarah yang terdiri dari heuristik, kritik, interpretasi dan historiografi. Hasil penelitian ini sebagai berikut : Proses awal terbentuknya Colonial Twon yang dibangun VOC bukanlah di tanah yang kosong sehingga mereka selalu membuat perjanjian politik dengan penguasa tradisional, di Pontianak VOC membuat perjanjian politik yang disebut Acte Van Investiture pada 5 Juli 1779, semenjak saat itu VOC mendapat wilayah seluas 1000x1000 m untuk dijadikan pusat administrasi mereka. Daerah yang dikelola oleh VOC itu disebut 'Duizen Vierkanten Paal'. Pasca perjanjian politik itu kemudian pontianak dapat dibagi menjadi dua wilayah kekuasaan, antara Kesultanan yang berada di sebalah utara yang disebut dengan kawasan Tradisional Town dan VOC sebalah selatan yang disebut dengan Colonial Town. Dua kawasan tersebut dipisahi oleh sungai Kapuas. Di Duizen Vierkanten Paal inilah VOC mulai membangun Kota Kolonial yang berlangsung dari tahun 17791791. VOC melihat potensi Pontianak sebagai daerah yang stratgeis untuk pusat perdagangan sehingga dengan cepat daerah ini berkembang. Orang-orang dari berbagai daerah pun berdatangan untuk bermukim di Pontianak. Pasca bubarnya VOC asetnya yang dimilikinya termasuk yang terdapat di kota colonial Pontiank diambil alih oleh Inggris melalui Rafles pada tahun 1811-1815 namun tidak terlalu berpengaruh pada pembangunan dan perkembangan Kota Kolonial. Pada tahun 1819 kemudian asset-aset VOC diambil alih oleh Pemerintah Hindia Belanda.
\end{abstract}

Kata Kunci: Kota Kolonial, Pontianak, VOC, Belanda.

\begin{abstract}
This research aims to find out how the initial process of the formation of the colonial city and its development in Pontianak during the Vereenigde Oost-Indische Compagnie (VOC) period that took place from 1779-1791. The research method used in this study is a historical research method consisting of heuristics, criticism, interpretation and historiography. The results of this study are as follows: The initial process of the formation of Colonial Twon built by the VOC was not in vacant land so they always made political agreements with traditional rulers, in Pontianak the VOC made a political agreement called Acte Van Investiture on July 5, 1779, since then the VOC got an area of $1000 \times 1000 \mathrm{~m}$ to be their administrative center. The area managed by the VOC was called 'Duizen Vierkanten Paal". After the political agreement, Pontianak could then be divided into two territories, between the Sultanate in the north called the Traditional Town area and the VOC as the south called Colonial Town. The two areas are separated by the Kapuas river. It was in Duizen Vierkanten Paal that the VOC began to build the Colonial City which lasted from 1779-1791. The VOC sees the potential of Pontianak as a stratgeist area for the center of trade so that it quickly develops. People from various regions also came to live in Pontianak. After the dissolution of the VOC its assets including those in the colonial city of Pontiank were taken over by the British through Rafles in 18111815 but had little effect on the development and development of the Colonial City. In 1819 voc assets were taken over by the Dutch East Indies Government.
\end{abstract}

Keyword: Colonial City, Pontianak, VOC, Netherlands.

Halaman | 111 


\section{PENDAHULUAN}

Sungai Kapuas yang melintang di tengah kota Pontianak memiliki pengaruh yang sangat kuat pada letak strategisnya. Sejak dulu wilayah ini menjadi primadona sebagai jalur perdagangan. Sejak dibuka oleh Sultan Syarif Abdurahman tahun 1771 Pontianak telah menjadi pintu masuk ke daerah-daerah hulu Borneo, hal ini semakin memperkuat posisi Pontianak sebagai daerah transito perdagangan.

Letak strategis Pontianak juga turut dipengaruhi oleh jalur perdagangan selat Malaka, sehingga jalur perdaganagan international terhubung dengan Singapura sebagai pusat perdagangan setelah runtuhnya Malaka dan menjadi jalur pelayaran CinaIndia. Hal inilah yang memberikan kemudahan transportasi sehingga banyak etnis tertarik untuk berdatangan ke Pontianak (Hasanuddin \& Kristanto, 2001).

Perdagangan yang semakin ramai membuat para pedagang dari daerah-daerah lain di Nusantara serta pedagang asing tertarik untuk tinggal menetap di Pontianak. Setelah mendapatkan izin dari Sultan untuk tinggal di Pontianak mereka membentuk perkampungan dengan nama asal daerah yang mendirikan perkampungan tersebut. Munculnya perkampungan pedagang tersebut telah memberikan dampak yang signifikan terhadap kemajuan Pontianak atau bisa dikatakan lebih memperkuat posisi Pontianak sebagai pusat Perdagangan (Alqadrie, 1984).

Masyarakat yang mendiami Pontianak juga menjadi lebih beragam serta secara aktif ikut meramaikan kegiatan perdagangan, kegiatan di Pelabuhan juga ikut ramai. Keberagaman etnis yang terbentuk dengan adanya perkampungan-perkampungan pedagang tadi menciptakan silang budaya, masyarakat secara postif menerima hal-hal baru yang datang dari luar kelompok mereka.

Hasanuddin (2000) mengatakan VOC telah aktif melakukan perdagangan pada pertengahan abad ke 18 di Kalimantan Bara tepatnya di Kerajaan Landak dalam rangka mencari komiditi Intan dan Lada. Ketika penobatan pangeran Syarif Abdurrahman sebagai Sultan Pontianak dilangsungkan, VOC memberikan pengakuannya denga mengirim utusan ke penobatan tersebut yakni Residen Rambang Willem Adrian Palm guna membuat perjanjian politik dengan
Kesultanan Pontianak. Penobatan Sultan Pontianak turut juga dihadiri oleh Raja Muda Riau, Raja Mempawah, Landak, Kubu, dan Matan

Setelah melihat kekuatan VOC yang semakin berkambang, Sultan Syarif Abdurrahman akhirnya menyetujui perjanjian politik dengan VOC pada tanggal 5 Juli 1779. Perjanjian yang dibuat tersebut dikenal dengan istilah Acte Van Investiture. Inti dari perjanjian politik itu lebih memberikan keuntungan kepada VOC dan memberikan kerugian kepada pihak kesultanan. Berdasarkan perjanjian politik tersebut VOC dapat meluaskan kepentingan dan kekuasaan politiknya serta berhasil memonopoli perdagangan di Pontianak dan daerah-daerah sekitarnya (Hasanuddin, 2014).

Menurut Alqadrie (1984) perjanjian yang dilakukan antara Kesultanan Pontianak Bersama VOC membuat VOC mendapatkan tanah di area selatan Istana yang dibatasi oleh sungai Kapuas. Tanah yang diberikan ke VOC itu berukuran 1000X1000 meter yang dijadikan VOC sebagai pusat adminsitrasi dan kegiatan Belanda seterusnya dijadikan sebagai lokasi kedudukan pemerintah Resident het Hoofd Westerafdeeling van Borneo. Penataan Pontianakpun kemudian diatur secara Bersama. Setelah mendapatkan tanah tersebut VOC walaupun tidak langsung dibangun namun dikemudian hari VOC mendirikan benteng yang diberi nama Fort Mariannen. Benteng tersebut dijadikan sebagai pusat pemerintahan serta pertahanan. Sebagaimana Benteng-benteng VOC di daerah lain Fort Mariannen mempunyai tembok besar di dalam dan area sekitar benteng bermukimlah para penjabat, pegawai dan tantara.

Daerah yang seluas 1000x1000 meter yang dikelola oleh VOC itu disebut "Duizen Vierkanten Paal" atau sering disebut tanah seribu. Tanah seribu ini berada sekitar area Taman Alun Kapuas (Asma Dz, 2013). Belanda dalam melakukan kolonialisasinya selalu membangun terlbih dahulu pusat kota yang digunakan untuk administrasi dan markas utamanya. Di Pontianak area "Duizen Vierkanten Paal" inilah Belanda membangun bangunan yang dijadikan pusat kota pemerintahannya untuk melakukan segala aktifitas

Setelah tanah seribu itu dipegang oleh VOC, Pontianak dijadikan sebagai pusat 
pemerintahan Kolonial (Eropesche Bestuur) untuk Westersche Afdeeling van Borneo serta sekaligus jadi pusat pemerintahan bumiputera (Inlandsche Bestuur) kerajaan Pontianak. Pontianak kemudian banyak didatangi untuk dimukimi karena perkembanganya sebagai pusat pemerintah dan pusat perdagangan, ini membuat Pontianak menjadi daerah pemukimana teramai jika dibandingkan daerah lainnya. Pada paruh abad ke-19 penduduk Pontianak berjumlah kurang lebih 6.000 orang. Penduduk yang mendiami Pontianak itu terdiri dari berbagai macam etnis anataralain Melayu, Arab, Bugis, Dayak, China dan Eropa. Masa itu kurang lebih terdapat sekitar 1.000 rumah (penduduk) serta Istana dan Etablissement (Komplek bangunan perkantoran dan perdagangan, banteng serta tempat tinggal orang Belanda (Asnan, 2019). Asnan (2019) mengatakan berdasarkan keterangan Veth (1854), Niuwenhuis (1900), Enthoven (1903) dan Doodeheefver (1936), sejak hadirnya kekuasaan Belanda, tata kota Pontianak telah menyiratkan potret kota Kolonial. Politik kolonialis Belanda menjadikan warga Hindia Belanda menjadi tiga kelompok. Politik ini menempatkan orang Belanda sebagai kelompok kelas satu dan China sebagai warga kelas dua, dan bimiputera sebagai kelompok kelas tiga. Politik kolonial yang realisis ini juga terlihat pada tata kota yang tumbuh dan berkembang seiring dengan eksploitasi politik, eksploitasi ekonomi dan penetrasi budaya kolonial di negeri ini. Maksudnya pada tata kota itu ada pemisahan tempat tinggal antar warga/penduduk kota, ada bagian kota yang khusus diperuntukan bagi orang Belanda dan China serta bumiputera.

Proses pembangunan kota colonial yang dijadikan pusat pemerintahan ini berlangsung cukup lama tidak serta-merta langsung jadi begitu saja. Prosesnya bagaimana belanda dalam menjadikan suatu daerah menjadi kota Kolonial ini menjadi menarik untuk diteliti. Kota yang memiliki ciri khas dan bangunan-bangunan yang memiliki yang bergaya indis. Belanda dalam membangun kota tersebut memiliki perencanaan yang mereka susun dalam rancangan pembangunan kota seperti mereka merancang kota Batavia, perencaaan yang rapi serta tersetruktur tersebut disebut sebagai 'Plan de Batavia'. Tentu kota kolonila yang mereka bangun di Pontianak juga memiliki perencanaanya sendiri (Basundoro, 2012).

Pembangunan kota Kolonial secara umum di Nusantara dapat kita bagi dalam dua priode yang berbeda (dalam perkembangannya). Priode awal dilakukan oleh VOC (tahun1779-1791) dan yang kedua adalah pasca VOC bubar kemudian semua asetnya diambil alih dan dikelola oleh Pemerinatahan Hindia-Belanda (Tahun 1819-1942) walaupun pada tahun 1811-1815 Inggris melalui Rafles dapat mengambil alih kekuasaan Belanda di Nusantara namun tidak terlalu berpengaruh pada pembangunan dan perkembangan Kota Kolonial.

Pada penelitian ini kita akan melihat bagaimana proses awal terbentuknya kota kolonial dan perkembanganya di Pontianak pada masa VOC yang berlangsung dari tahun 1779-1791.

\section{METODE PENELITIAN}

Penelitian yang penulis lakukan ini menggunakan metode penelitian sejarah yang memiliki beberapa tahapan yakni (1) heuristik, (2) verifikasi, (3) interpretasi dan (4) historiografi (penulisan) (Gottschalk, 1975).

Tahapan pertama yang penulis lakukan adalah Heuristik, pada tahap ini penulis melakukan pengumpulan data atau sumber sejarah yang berkaitan dengan Colonial Twon Pontianak baik itu sumber primer maupun sumber sekunder. Tahapan kedua penulis melakukan verivikasi yang bisanya sering disebut sebagai kritik sumber. Sumber yang diverivikasi adalah sumbur atau data yang telah penulis kumpulkan pada tahap pertama. Kuntowijoyo (2003) mengatakan bahwa kritik sumber sangat penting untuk dilakan guna mengukur validitas sumber atau data yang kita kumpulkan. Teknik dalam melakukan verivikasi menggunakan kritik intren dan kestren.

\section{HASIL PENELITIAN DAN PEMBAHASAN}

\section{Proses Awal terbentuknya Colonial Twon}

Kota Kolonial merupakan kota yang dibangun dan dikembangkan orang-orang Eropa di daerah-daerah yang baru mereka didatangi. Hal serupa juga didefinisikan oleh 
Taylor (2009) kota kolonial yakni kota kloni yang dikembangkan orang-orang Eropa. Pada tahap selanjutnya daerah itu berkembang menjadi pusat pemerintahan penjajahan

McGee (1967) membagi tiga ciri dari Kota Kolnial antaralain: 1) Permukiman yang sudah stabil. Di wilayah kontak dagang ada granisun dan permukiman untuk para pedagang, 2) Adanya rumah untuk para pemerintah kolonial yang mengatur berlangsungnya pemerintahan kolonial termasuk menjalin kontrak politik dengan penguasa pribumi. Dan 3) Kota Kolonial yang dibangun letaknya selalu dekat dengan laut dan atau sungai, hal ini untuk memudahkan kapal-kapal mereka untuk berlabuh dan melakukan pengangkutan barang ekspor.

Nusantara ketika para Eropa datang bukanlah tanah kosong, ada penguasa Tradisional yang sudah berkuasa sejak lama dan membangun daerah kekuasaannya tersebut. Kedatangan mereka merubah struktur kekuasaan dan pola perkembangan kota di Nusantara. Sebagaimana kedatangan Belanda (VOC) ke Pontianak, Sultan Syarif Abdurahman sudah membuka terlebih dahulu daerah ini dan kemudian mendirikan Kesultanan (baca: Kerajaan). Kota Kolonial pertama yang dibangun Belanda di Nusantara (Indonesia) adalah Batavia yang sebelumnya bernama Jayakarta (sebelum kedatangan Portugis disebut dengan Sunda Kelapa). Tahun 1619 Batavia dibangun Belanda. Pembangunan Batavia ini kemudian menjadi fase baru dalam perkembangan kota-kota lain.

Kota Kolonial yang dibangun oleh Belanda memilik rancangan yang rapi serta perencanaan yang teratur, sehingga kota kolonial yang dibangun memiliki kemiripan dengan apa yang mereka bangun di kota-kota di Eropa. Bagi kota yang dekat dengan laut berpola kotak-kotak dengan pembatas antarblok dibuatkan jalan dan kanal. Sebagaimana kota-kota yang ada di Belanda, kanal yang dibuat selain jadi pembatas antarblok juga digunakan untuk jalur transportasi. Bangunan yang dibangun didominasi corak bangunan khas Eropa atau bergaya Indis (Basundoro, 2012).

Di Kota Kolonial, Benteng adalah salah satu bangunan yang sangat penting, pembangunan Benteng sebagai bentuk pertahanan dan pemanfatanya sebagai perdagangan. Benteng dipandang perlu oleh para kolonial karena rasa khawatir diserang oleh penguasa Tradisional.

Benteng biasanya menjadi bangun pertama yang dibangun oleh VOC sebelum membangun kota colonial. Benteng dibangun yang memiliki fungsi selain pertahanan juga digunakan sebagai gudang penyimpanan komoditi yang akan dibawa ke Eropa. Setelah mereka berhasil membuat kekuasaannya meluas di daerah itu baru mereka membangun 'twonhall' bserta bangunan lainya diluar dari area benteng. Selain itu meraka biasanya mendirikan rumah panti asuahan yang digunakan untuk menampung anak-anak dari orang Belanda yang orangtunya sudah meninggal, panti asuahn ini didirkan dekat dengan twonhall (Damayanti \& Handinoto, 2005).

Di area dalam benteng orang Eropa mendirikan bangunan dengan bahan batu bata yang didatangkan dari Eropa begitung dengan para pekerja tukangnya. Bangunan yang mereka diririkan anatara lain adalah gereja, rumah dan bangunan lainya dengan tata letak dan arsitektur bergaya Eropa. Pada masa-masa inilah berkembanglah bangunan khas Kolonial di Indonesia (Purwanto, 2005).

\section{Perkembangan Pembangunan Colonial Town Pada Masa VOC Tahun 1779-1791}

Sebelum kedatangan VOC daerah ini terlebih dahulu dibuka dan dibangun oleh Syarif Abdurrahman Alkadrie pada tahun 1771 (14 Radjab 1185 H). Pembukaan hutan dilakukan oleh Syairf Abdurrahman Alkadrie di daerah persimpangan sungai yakni persimpangan sungai Landak, Kapuas Kecil dan Sungai Kapuas, di sana beliau mendiri balai dan rumah yang digunakan sebagai temapt tinggal. Pada $1192 \mathrm{H}$ bertepatan pada tahun1779 Syairf Abdurrahman Alkadrie dikukuhkan sebagai Sultan Pontianak.

Pontianak berada pada posisi yang sangat strategis, dengan berada di muara sungai Kapuas dan berada di persimpangan sungai menjadikan Pontianak sebagai pintu gerbang untuk masuk ke daerah-daerah pedalaman Kalimantan. Selain itu Pontianak juga berada di jalur perdagangan karena dekat dengan Malaka terlebih ketika Singapura menjadi pusat perdagangan pasca runtuhnya Malaka, ini membuat Pontianak menjadi daerah transito perdagangan daik dari Barat maupun Timur Nusantara (Hasanuddin, 2016). 
Hal ini sependapat dengan yang dikemukana oleh Listiana (2009) bahwa jalur startegis ini membuat Pontianak masuk dalam jalur perdagangan Internasional dan menjadi akses lalu lintas antara Pontianak dengan daerah-daerah hindterland di Borneo Barat. ini membuat Sultan Syarif Abdurahman mampu menjadikan Pontianak menjadi daerah yang berkembang sebagai pusat pelayaran dan perdagangan terutama untuk daerah Borno Bagian Barat. Letak Strategis yang dimaksud dapat kita lihat pada peta di bawah ini :

Sejak daerah ini berkembang kemudian banyak pedagang datang dengan mengadakan hubungan perdagangan dengan kesultanan Pontianak, seperti Bugis, Melayu, Cina, Sanggau, Sukadan, Mempawah dan Sambas (Kartodirjo, 2014). Dan ada juga orang Dayak yang berdatangan lalu membuka perkampungan sepanjang tepian sungai Ambawang (Hasanuddin \& Kristanto, 2001).

Selain orang-orang pribumi yang tertarik berdatangan dan berkuminan di Pontianak, orang Belanda juga tertarik untuk mendapatkan tempat di kawasan strategis ini. Belanda yang pada saat itu diwakili oleh VOC sebenar sudah lama masuk ke Borneo Barat (Istilah yang sering digunakan saat itu untuk menyebut Kalimantan Barat). Di Indonesia nilai penting pelabuhan Sumatra dan Kalimantan bagi VOC mulai berkurang. Sedangkan Kepulauan Rempah masih tunduk dibawah VOC. Kepentingan VOC masih terfokus pada Jawa dan bahkan pengaruhnya di kawasan itu semakin melebar (Leur, 2014). Namun sejak daerah ini mulai berkambang sebagai pusat perdagangan VOC mulai tertarik untuk memperkuat pengarunya di Kalimantan Barat.

VOC diketahui sudah mendirikan sebuah kantor dagang di Sukadana sejak 1608, kemudian pada tahun 1609 juga mendirikan kantor dagang di Sambas. Namun, keberadaan kantor dagang VOC di kedua wilayah tersebut harus berakhir dengan petaka. Pada tahun 1610, kantor dagang Sambas diserang dan seluruh pegawainya dibunuh. Hal yang sama juga terjadi di Sukadana pada tahun 1622. Ketika Kerajaan Sukadana dalam situasi perang dengan Kerajaan Mataram di Jawa, kantor dagang VOC yang berdiri di kerajaaan ini dihancurkan, meskipun pegawainya tidak ada yang dibunuh seperti yang terjadi di Sambas.
Perusahaan dagang milik Belanda ini baru sukses mengukuhkan hegemoninya saat memanfaatkan konflik yang terjadi antara Kerajaan Landak dan Sukadana pada tahun 1698. Kerajaan Landak yang merupakan vasal dari kerajaan Banten, bersama dengan VOC, menyerbu Sukadana dan berhasil mengusir penguasa Sukadana hingga ke pedalaman. Karena Banten juga telah ditaklukkan VOC, maka dapat dikatakan bahwa VOC telah berhasil menunjukkan supremasinya di Pantai Barat Kalimantan (Westkust van Borneo) (Abubakar et al., 2019).

Belanda melihat peran dan posisi strategis Kesultanan Pontianak dan sebaliknya juga dimana perkembangan kesultan Pontianak yang baru berdiri itu berkonflik dengan beberapa kerajaan lain yang ada di Kalimantan Barat. Pihak VOC mengakui kekuasaan Sultan Syarif Abdurrahman. Gubernur Jendral VOC Reinier de Klerk mengutus Residen Rembang Willem Adrian Palm untuk mengadakan hubungan kontrak politik yang disebut dengan "Act van Investiture" pada tanggal 5 Juli 1779 (Hasanuddin, 2014). Melalui perjanjian itu menandakan kedudukan Belanda untuk pertama kalinya di Pontianak. VOC mendapat tanah seluas 1.0000 pal (1 pal disetarakan dengan $1.506,94$ meter) yang disebut Duizen Vierkanten Paal atanu Tanah Seribu (Listiana, 2014).

Pasca pernajian politik itu kemudian pontianak dapat dibagi menjadi dua wilayah kekuasaan, antara Kesultanan yang berada di sebalah utara yang disebut dengan kawasan Tradisional Town dan VOC sebalah selatan yang disebut dengan Colonial Town. Dua kawasan tersebut dipisahi oleh sungai Kapuas.

Tanah Seribu yang dikelola oleh VOC dijadikan tempat kegiatan kedudukan pemerintahan Resident hetHoofdplaats Westerafdeeling van Borneo dan Militernya. Proses tersbut merupakan pendudukan awal VOC di Pontianak. Tanah yang dikelola oleh VOC ini merupakan tanah gambut dan mudah larut oleh Air sehinga ketika membangun sarana pertahanan maupun perumahan bagi anggota-anggota garnisun meliter sangat kesultan (Veth, 2012).

Untuk mengatasi kesulitan tersebut langkah awal yang dilakukan oleh VOC adalah membuat parit-parit (Kanal-kanal) 
kecil di sekelilingnya dilengkapi jembatan kayu disetiap sudutnya sebagai batas wilayah pembangunan tahap pertama. Pembangunan Parit atau Kanal ini sangat penting, selain untuk mengatasi tanah gambut tadi parit-parit ini juga bias difungsikan sebagai upaya pertahan dan keamanan kota, sarana transportasi dan pencegahan banjir. Di sebalah utara dibangun parit sejajar dengan aliran sungai Kapuas Kecil dengan ujung barat laut ditandai oleh jembatan kayu yang dikenal dengan gertak satu. Sebelah barat dibangun Parit sungai Jawi dengan gertak dua di sudut barat dayanya. Sebelah timur dibatasi oleh parit besar dengan gertak empat disudut timur lautnya. Sebalah selatan dibangun parit di sisi Palmenlaan (Jalan pohon-pohon palem/ sekarang jalan Merdeka) dengan gertak tiga disudut tenggara dan batas selatan pembangunan tahap pertama ini adalah Tembok Baru (Listiana, 2009).

VOC kemudian membangun kantor dagang, pembangunan ini belum bisa dipasttikan kapan namun jika terhitung dari tahun perjanjian Act van Investiture yakni tahun 1779 berlangsung hingga tahun 1784 . Saat itu pada masa Wolter Markus Stuart sebagai Residen Borneo Waster Afdeeling yang pertama. Berdasarkan perjanjian yang dibuat agar kantor dagangnya dapat dilindungi VOC membuat benteng kecil dan diletakkanlah 6 meriam serta satu orang perwira dan juga 25 serdadu (Listiana, 2009).

Benteng yang dibangun VOC diberi nama Meriannen, pembangunan benteng ini memang sudah menjadi ciri dari Kolonial. Ada kekhawatiran dari Kolonial diserang oleh pihak-pihak yang berkonflik denganya. Konflik yang terjadi dan meraka alami membuat mereka merasa tidak aman dan nyaman, oleh sebab itulah mereka mulai membangun benteng disetiap kotanya. Benteng yang dibangun kurang lebih memiliki ketinggian sekiyar 2,5 m dengan ketebalan $1 \mathrm{~m}$. Hampir di setiap kota-kota besar dan pusat dagang dapat dijumpai benteng-benteng seperti itu di Indonesia. Selain untuk mengamani diri dari konflik benteng-benteng tersebut juga dijadikan sebagai markas militer serta hal lain yang dianggap penting dan strategis oleh Belanda. Contohnya di Ambon, Ternate, Makasar, Banten, Batavia dan Semarang. Di Ambon dibangun benteng pada tahun 1580 dengan nama Benteng "Victoria", di Makasar bernama Benteng "Rotterdam", di Jakarta pada tahun 1611 dengan nama Benteng "Batavia" dan di Semarang dengan nama Benteng "Vifjhoek" (Purwanto, 2005).

Selain itu benteng-benteng yang dibangun oleh VOC begitu juga yang dibangunya di Pontianak didirikan di tepi sungai atau dekat laut difungsikan untuk temmpat penyimapanan hasil komoditi yang akan diekspor ke Eropa. Sekitar kawasan benteng itu juga akan dibangun pelabuhan untuk menunjang perdagangan yang meraka lakukan. Setelah kedudukannya kuat dan menguasai kota secara keseluruhan baru ia keluar dari bentengnya dan mendirikan sebuah 'townhall' yang dikelilingi oleh bangunan pelengkap lainnya (Damayanti \& Handinoto, 2005)

Masa awal pembangunan kota kolonial yang dilakukan oleh VOC ini tidak terlalu lama, seiring melemahnya VOC karena defisit yang terjadi di tubuh VOC akibat adanya praktek korupsi dan suap. Sejak tahun1790 direksi memutuskan untuk menutup kantor-kantor dagang VOC di Pontianak maupun diseluruh Borneo bagian Barat. Keputusan ini berlaku sejak 8 Oktober 1791 (Veth, 2012).

Akibat penutupan kantor-kantor dagang VOC tersebut, perdagangan di Pontianak juga mulai merosat, walaupu aktifitas perdagangan masih berlangsung terutama bagi orang-orang Inggris, portugis dan yang lainnya. Namun factor eksternal Pontianak juga menjadi penyebeba merosotnya perdagangan di Pontianak, misalnya adanya perkembangan Pulau Pinang dan perang terus menerus Inggris Belanda (Listiana, 2009).

Ricklefs (2008) menyebutkan adanya persaingan antar kepentingan penjajah di Kalimantan terutama Inggris dan Belanda yang memiliki kepentingan jelas atas kekuasaanya di sana. Walaupun Inggris sebenarnya tidak terlalu menganggap Kalimantan berarti namun yang paling penting bagi Inggris adalah letak strategis Kalimantan yang diapit dua jalur pelayaran yakni India dan Cina. Inggris juga mengkhawatirkan adanya kemungkinan hadirnya bangsa Eropa lain di Kalimantan terutama di Kalimantan Utara dan Kalimantan Barat.

Melihat tumbangnya VOC Inggris melalui East India Company (EIC) menggantikan kekuasaan VOC dalam waktu 
yang sangat singkat (1811-1816). EIC kemudian menyerahkan kembali kekuasaanya kepada pemerintahan HindiaBelanda. Pemerintah Hindia-Belanda mengamnbil alih apa yang telah dibangun oleh VOC baik kekuasaan politiknya maupun kota klonialnya. Hal tersebut ditujukan untuk mendapatkan kekuatan politik dan keuntungan dari upeti dan perdagangan (Hasanuddin, 2014).

\section{KESIMPULAN}

Kota Kolonial yang dibangun oleh bangsa Belanda di Nusantara tentu bukan berada di daerah yang kosong tanpa penghuni. Mereka membangun di kawasan milik penguasa Tradisional. Bangsa Belanda bisa medapatkan tanah untuk membangun sebuah kota dengan melakukan perjanjian politik dengan penguasa tradisional di daerah itu. Hal ini dapat kita lihat dalam narasi sejarah Pontianak. perjanjian politik yang disebut Acte Van Investiture pada 5 Juli 1779, semenjak saat itu VOC mendapat wilayah seluas $1000 \times 1000 \mathrm{~m}$ untuk dijadikan pusat administrasi mereka. Daerah yang dikelola oleh VOC itu disebut 'Duizen Vierkanten Paal". Di tanah inilah VOC membangun Kota Kolonialnya. Pembangunan yang dilakukan VOC tidak berjalan terlalu lama selepas VOC dinyatakan bubar kantor-kantor dagangnya pun ditutup termasuk yang berada di Pontianak. Melihat sitausi itu Inggris/EIC dibawah Rafles masuk ke nusantara termasuk di Pontianak namun tidak berlangsung lama yakni pada tahun 1811-1816. Kemudian asset-aset VOC pada tahun 1819 diambil alih oleh Pemerintah Hindia Belanda, kemudian mereka melanjutkan pembangunan Kota Kolonial di Belanda.

\section{DAFTAR PUSTAKA}

Abubakar, A., Krisdiana, R., Usman, S. D., And, U. F., Wibawa, M. A., \& Akbar, A. (2019). Menegakkan kedaulatan dan ketahanan ekonomi; Bank Indonesia dalam Pusaran Sejarah Kalimantan Barat. Jakarta: BI Institute.

Alqadrie, S. I. (1984). Sejarah Sosial Daerah Kotamadya Pontianak. Jakarta: Depdikbud, Proyek Inventarisasi dan
Dokumentasi Sejarah Nasional.

Asma Dz, A. (2013). Pontianak Heritage dan Beberapa yang Berciri Khas. Pontianak: Literer Khatulistiwa.

Asnan, G. (2019). Sungai Kapuas, Pemukiman dan Masyarakat di Tepiannya dalam Empat Catatan dari Tiga Zaman. Makalah dipersentasikan pada Dialog Budaya 'Peradaban dan Ekosistem Kebudayaan Kapuas: Antara Isu, Masalah dan Gagasan Lokalitasnya'. 20 September, Pontianak.

Basundoro, P. (2012). Pengantar Sejarah Kota. Yogyakarta: Penerbit Ombak.

Damayanti, R., \& Handinoto. (2005). Kawasan "Pusat Kota" Dalam Perkembangan Sejarah Perkotaan Di Jawa (Rully Damayanti, et al,). Dimensi Teknik Arsitektur, 33(1), 34-42. https://doi.org/https://doi.org/10.9744/d imensi.33.1.

Gottschalk, L. (1975). "Understanding History: A Primer of Historical Method", a.b, Nugroho Notosusanto, Mengerti Sejarah. Jakarta: Universitas Indonesia Press.

Hasanuddin. (2000). Sejarah Pemerintahan Potianak dari Masa ke Masa. Pontianak: Romeo Grafika.

Hasanuddin. (2014). Pontianak Masa Kolonial. yogyakarta: Penerbit Ombak.

Hasanuddin. (2016). Politik Dan Perdagangan Kolonial Belanda Di Pontianak. Patanjala: Jurnal Penelitian Sejarah Dan Budaya, 8(2), 203. https://doi.org/10.30959/patanjala.v8i2. 73

Hasanuddin, \& Kristanto, B. (2001). Proses Terbentuknya Heterogenitas Etnis di Pontianak pada Abad ke-19. Humaniora, 13(1), 64-81.

Kartodirjo, S. (2014). Pengantar Sejarah Indonesia Baru: 1500-1900 Dari Emporium Sampai Imperium. Yogyakarta: Penerbit Ombak.

Kuntowijoyo. (2003). Metodologi Sejarah. yogyakarta: Tiara Wacana.

Leur, V. (2014). Perdagangan dan Masyarakat Indonesia; Esai-Esai Tentang Sejarah Sosial dan Ekonomi Asia. Terjemahan Indonesian Trade and Society; Essays in Asia Social and Economic History, Holland, Dordrecht: Foris Publication, 1983). Yogyakarta: Penerbit Ombak.

Listiana, D. (2009). Ibu Kota Pontianak 1779- 
1942; Lahir dan Berkembangan Sebuah

Kota Kolonial. Pontianak: Balai Pelestarian Sejarah dan Nilai Tradisional Pontianak.

Listiana, D. (2014). Dari Pacht Pasar Ke Pasarfonds: Pasar Pontianak Dalam Kebijakan Ekonomi Kolonial. Widyariset, 17(1), 83-92.

McGee. (1967). The Southeast Asian City: A Social Geography of the Primates Cities of Southes Asia. London: G. Bell \& Sons.

Purwanto, L. M. F. (2005). Kota Kolonial Lama Semarang (Tinjauan Umum Sejarah Perkembangan Arsitektur Kota). Dimensi Teknik Arsitektur, 33(1), 2733.

https://doi.org/https://doi.org/10.9744/d imensi.33.1.

Ricklefs, M. (2008). Sejarah Indonesia Modern 1200-2008. Terjemahan dari A History of Modern Indonesia Since c. 1200 Fourt Edition, terbitan Palgrave. Jakarta: Penerbit Serambi.

Taylor, J. G. (2009). Kehidupan Sosial Di Batavia Orang Eropa Dan Eurasia Di Hindia Timur. Jakarta: Masup.

Veth, P. (2012). Borneo Bagian Barat: Geografsi, Statistik, Historis Jilid 1, Terjemahan Borneo's westerAfdeeling,Geographisch, Statistisch, Historisch voorafgegaan door eene algemeene schets des ganschen eilands a.b P.O.C.Yeri. Pontianak: Isntitut Dayakologi. 